\title{
旧・新住民の意識を通してみた幹線道路沿道地域環境改善に関する考察 一千葉県船橋市立法典小学校区の木下街道沿道を事例に一 \\ A STUDY ON THE IMPROVEMENT OF ENVIRONMENT WITH RESIDENTS' OPINION
}

A case study of the Hoden Primary School district on the Kioroshi road

奥平純子*, 北原理 雄**

\section{Junko OKUDAIRA and Toshio KITAHARA}

\begin{abstract}
This paper examines and clarifies the opinions of residents about the improvement of a narrow and dangerous footpath alongside main traffic route (the Kioroshi road), where the environment has not been improved over numerous years. By the analysis, it is clarified that the opinions of landowners for improvement of the environment are different from those of pedestrians. So, we study how to fill the gap and to improve the environment by residents. The results can be summarized as follows: 1) by knowing the opinion of the landowners, the ideas of pedestrians change to improve the environment together with landowners, 2) the women between the age of forty and forty-nine are thought as the key person for connecting community members of region..3) it is important to recognize that "niwadoushi" which was adopted for widening the footpath at this area in the past is an effective method for improvement of community environment and ancestral wisdom for this area.
\end{abstract}

Keywords : Main traffic route, Footpath Environment, Local Community, Pedestrian, Landowner, Niwadoushi 幹線交通路, 歩道環境, 地域のコミュニティ, 歩道利用者, 地権者, 庭どおし

\section{1. はじめに}

\section{1 背景}

幹線交通路沿道地域では、狭く危険な歩道の改善が長年進まない ため、地域の人びとの生活に大きな影響を及ぼしているところが多 くある。本対象地の街道は、1963 年に都市計画道となり幹線交通路 と化した。こうした街道はかつて、人が歩く空間であり沿道住民に とっては、地域のコミュニティ形成のための核的空間であったと考 えられる。

高度経済成長期以降、大都市圏を中心と寸る都市部に人口が流入 し、都市近郊に多くの市街地が開発された。旧街道周辺にもこうし た市街化地域が広がり人口が増加した。人口が増えたにもかかわら ず街道は主要な自動車道となったため、街道の徒歩利用によって生 じていた地域の人びとの交流は激減した。また近年では様々な地域 で、トラブルや煩わしさの伴う近所づきあいを避ける人が増え、通 勤や娛楽なども地域外で過ごすことの多いことから、自然発生的に コミュニティが成立する基盤が少なくなっていると言われている ${ }^{11}$ 2) 3）4）5。コミュニケーションの場がなければ、地域への共属感 情も生じにくくコミュニティも成立しにくい。
一方、地域コミュニティの重要性が再認識され、町並みや景観を 守る原動力となっていたコミュニティは、近年まちの安全と安心の くらしを支える力として期待されている ${ }^{6}$ 。 。本対象地域（図 1）に ある危険な歩道のように、地域の日常生活にかかわる環境問題に対 応する力についても、地域のコミュニティの存在は大きな影響を与 えると考えられる。

\section{2 研究の目的}

本研究は千葉県船橋市立法典小学校区を対象とする一連研究 7) 8) の継続である。既報では、(1)沿道小学校の児童および保護者に対し て、歩道環境に関する評価調查を行うとともに大気污染物質等の実 測を行うことにより、本地域の歩道環境に対して住民が共通に問題

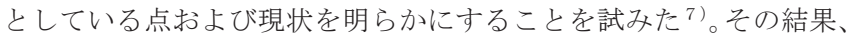
車の量を減らし歩道を広げることによる安全性や大気環境の改善、 子どもにとって豊かな経験のできる環境づくりなどの視点を入れた 地域全体からの改善が必要であることが明らかになった。(2)本地域 の幹線道路が現在のような状況になった理由を歴史面から調查し、 行政および自治会へのヒアリング結果と合わせ、歩道拡幅に時間の かかる理由を考察した ${ }^{8)}$ 。その結果、地域で県の拡幅事業を見守る
* 千葉大学大学院工学研究科 博士 (工学)

** 千葉大学大学院工学研究科 教授·工博 
状態が続いていること、静かに見守る背景には、歩道利用者と地権 者が近所であること、および「県が今拡幅注1)をがんばっているの ならば、県の立場もあるので横から住民がはいっていくのはどうか と思う」という自治会の県への気遣いが見られることなどが明らか になった。そのため、利用者と地権者がともに納得して持続的に利 用できる方法を話し合えるよう、市などの第 3 者側に立つ組織の調 整役的介入が必要ではないかということが考えられた。

これらの研究結果を踏まえて本研究では、これまで意見交換があ まり行われたことのない旧住民（地権者）と新住民（歩道利用者） に対して、地域環境の問題に関するアンケートやヒアリングを行っ た。その結果得られた地権者の思いを報告会や勉強会で地域の人び とに伝えることにより、さらに人びとの意見を引き出した（図 2）。 本論では、地域環境にたい寸るこうした住民の声を通して、環境改 善の可能性について考察することを目的とする。

\section{3 既往研究}

本研究対象地の場合、大きく区分すると住民は、新田村として開 発された時期から人口が増える前までに、街道沿道に居住した沿道 住民（旧住民）と、市街化された後から増加している住民（新住民） がいる。旧・新住民の交流は、混住社会におけるコミュニティ形成 上の大きな課題の一つとしてこれまで取り上げられ研究されてきた 2）4）すなわち、旧・新住民相互のつきあい関係は、学校や団体で のつながりを契機とするものが主で、近接して居住していることに より親しい関係が生まれることはほとんどなく、旧・新住民の交流 が進展しないことが指摘されている。かつての混住化から一定の時 間を経過した地区についての分析では、旧住民との深い交流は、農 家や旧・新住民の高齢者層が中心となって拡大すること、旧・新住 民の高齢者層や血縁者のいる新住民は、旧・新住民の交流促進のパ イプ役となりうることが記されている ${ }^{5)}$ 。しかし環境改善について の問題をとりあげ、旧・新住民の意識差を分析することは行われて いない。

また住民の意識については、意識調査アンケートの調査票作成に あたって、ワークショップを活用した効果を分析したものがある6)。 地域の基礎調査をもとに作成した意識調査アンケートと地元住民の 手によるアンケートにより、ホンネとタテマエの防災意識について 分析している。しかし旧・新住民をとりあげ意識の差異について述 べられたものではない。

住民意識の差異を改善するには、住民同士のコミュニケーション の機会を増やすことが要になる。既往研究では、空間構成の特徵的 な要素の 1 つである敷地間通路に着目し、様々な隣家関係パターン を明らかにした研究 9 )、地域の行事における活動から地区のコミュ ニティが継続している理由について、数多いキーパーソンが少しず つ交代して更新されることを明らかにした研究 ${ }^{1)}$ 、地区の飲夕屋の ようなコミュニケーションの場となっているケースの分析 10)など、 豊かなコミュニティが形成されているところについての分析が多い。 しかし旧・新住民意識の差異をいかにして埋めるかについては述心゙ られていない。

\section{2. 対象地の概要と問題点}

\section{1 拡幅協力に時間のかかる危険な歩道}

都市部および大都市と隣接した地域の旧街道や脇街道は、大正期
から高度経済成長期にかけ都市計画道路に決定され、幹線交通路と なった 11)。こうした市街地では、歩道がほとんど確保されないまま 幹線交通路化し現在に至っている所が多数ある。その結果、歩道環 境と歩道利用者、歩道利用者と沿道地権者などとの間に様々な軋䡚

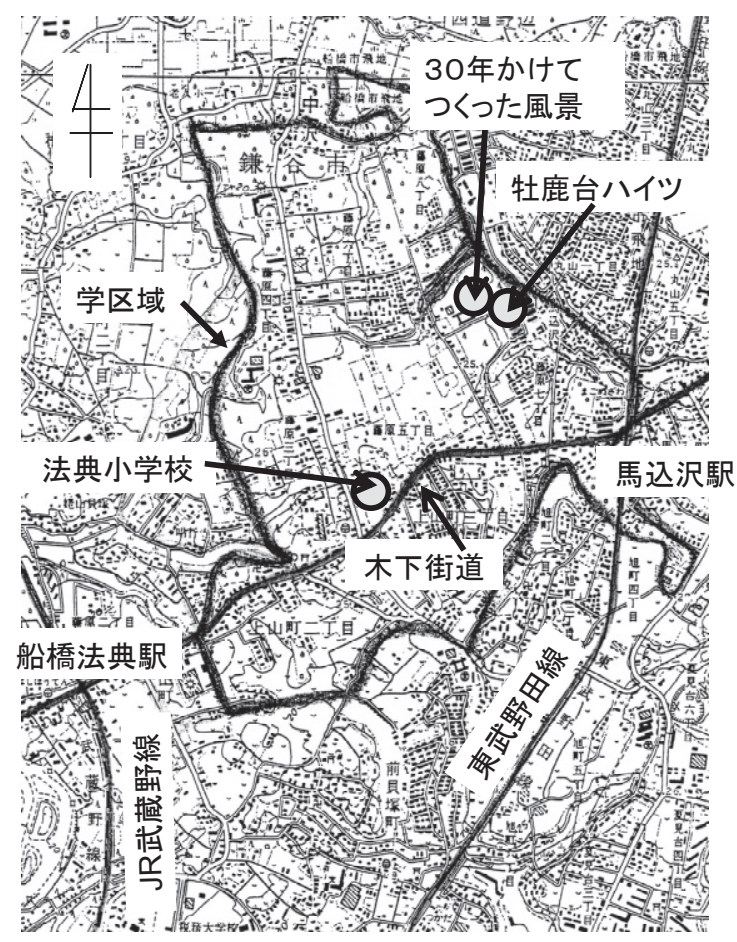

図 1 調查対象地

調査1

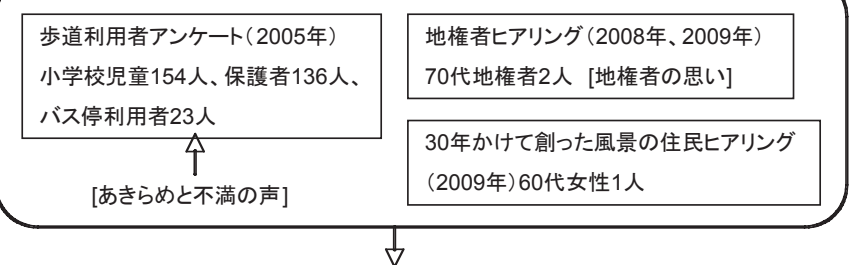

地権者の思いを含めて報告(2009年)

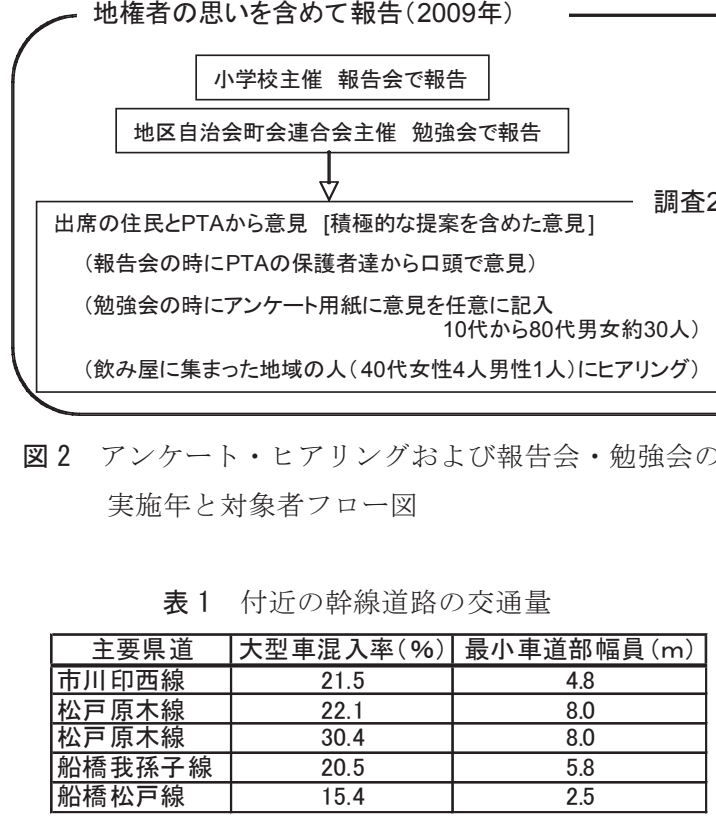


が生じている。歩道の拡幅整備のためには、法律による強制的なセ ットバックなどの手段が一般的に行われている。対象地の場合、市 の道路位置指定の審査を行う審查課の話しでは、建築基準法第 42 条で 2 項道路に指定されている。そのため、建物を新しく建てる場 合あるいは改築する場合には、市に申請を行いセットバックしなけ ればならない義務が生じ拒否することはできない。このとき拡幅さ れる土地は地権者からの無償の提供によるものである、とのことで あった。こうした方法により少しずつでも確実に拡幅が進む一方、 いつまでもセットバックを行わない家の壁だけが歩道に飛び出すこ とがあるなど、拡幅協力には非常に長い時間がかかっている。住民 は何十年も狭く危険な歩道を利用し続けることを強いられる状況と なっており、地域のコミュニケーションの場を含めた人びとの生活 面で大きな影響を及ぼしていると考えられる。

\section{2 学区内にある幹線道路}

調查は、千葉県船橋市にある船橋市立法典小学校（以下、法典小） の学区で行った。江戸時代に整備され、現在、木下街道と通称され る県道（主要地方道、千葉県道 59 号市川・印西線）が、本学区を 南西から東北に貫いている (図 1)。調查を行った学区内の木下街道 は約 $2 \mathrm{~km}$ 強である。調査範囲の最小歩道幅員は縁石幅を入れない と約 $0.6 \mathrm{~m}$ であった（図 3、図 4)。法典小は木下街道の沿道に位置 する。最寄り駅へ行く最短の道が木下街道のため、通勤、通学、買 い物に利用する生活道でもある。特に小学校児童と女性の保護者の 徒歩利用率が高い8)。

付近の幹線道路の交通量と比較した結果を表 1 に示す。大型車混 入率 $20 \%$ 以上の車道では、木下街道の最小車道部幅員が最も狭い。 すなわち車道部の狭さに対し大型車混入率が比較的高い車道である。

\section{3 コミュニティの核が見えにくくなった沿道地域}

本地域は、新田開発により木下街道沿道に開発された村だった。 そのため木下街道沿道両脇には、古くか らの住宅が連なっている。都市計画道路 決定前の木下街道は、千葉県一の悪路と いわれるほど、ぬかるみのひどい道だっ た。1928 年以前から悪路改善のために沿 道住民は、木や砂利を入れる（村中で 1 戸あたり 30 日の勤労奉仕）などの公的 事業を行い、積極的に道路整備に関与し てきた ${ }^{8)}$ 12)。すなわち労働力や寄付金な どを地域の共同体に所属する一住民とし て、旧住民の家では自分達でまかなうこ とによって、公的事業を進める時代を経 験している。1963 年に都市計画道路に決 定されたが、このときに悪路を舗装道路 にしたいという住民の要望をまとめた県 への申請は、これまでの共同体としての まとまりが住民の意見をまとめる力とな り実現に至ったと推測される。当時、近 所で会うたびに「なんとかしたいものだ」 という話が出たと地権者から聞いている。 道路の舗装を住民は望んだが、幹線交通 路化したことに対しては、ヒアリング時
に地権者から、まさかこんなに交通量が多くなるとは思わなかった という戸惑いの声が聞かれた。

また都心と千葉市から $30 \mathrm{~km}$ 圈内のため、沿道住宅背後の畑地は、 特に高度経済成長期に宅地化が進んだ。現在もミ二開発が行われ、 2011 年には法典小は児童数 1155 人と市内で 2 番目に多い大規模校 となった 13)。宅地開発が続いているため、人口は今後も増加傾向 にある。新住民の割合が大きくなると農家は積極性を失い、このよ うな類型の集落にあっては、意識の上ではコミュニティ形成の核と なるものが見られない4)、とあるように、現在の本地域ではコミュ ニティ形成の機会が発生しにくく、地域全体としてとらえたときに コミュニティの核となるものが見えにくい状況ではないかと推測さ れる。

\section{4 行政および自治会の対応}

これまでに地元自治会および行政は、木下街道の歩道環境改善に 対して、以下のような対応を行ってきた。

(1) 地元自治会は、自ら木下街道歩道部を丹念に歩き、歩道の危険箇 所などの歩道部状況を地図に落とした調査結果資料を作成している 8)。さらに、歩道上の電柱を移すための交渉を電力会社と行うなど 少しでも歩道を広く安全に利用できるよう努力を続けている。 木下街道そのものの交通渋滞解消のために、自治会の中で交通安全 対策委員を発足させ、マイカー利用者の乗り換え策として、住宅地 にミニバスを開通させるなど強い実行力と主体性を持っている。

(2)道路管理者である県の話では、少しずつだが確実に歩道拡幅を進

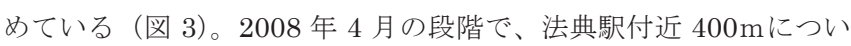
て上山町側は 1 件を残して拡幅が終了し、引き続き藤原町側を行っ ているが、地権者からの要求が非常に多く拡幅協力にはかなり時間 がかかるとのことであった注1）8。

(3)沿道地権者の話によると、県は住宅を建て替えるときにはセッ

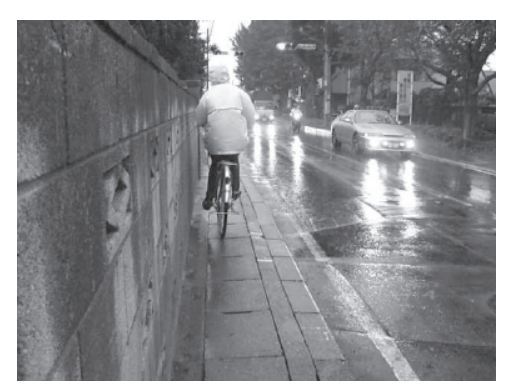

(1) 歩道幅員 $0.6 \mathrm{~m}$

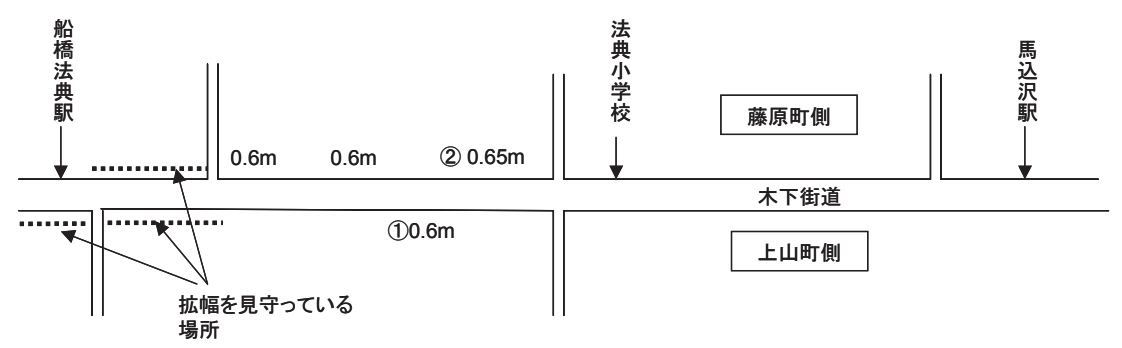

図 3 拡幅場所、狭い歩道と車道の様子および撮影場所 
トバックしないと許可を降ろさないよう法律で規制している。すな わち、現在建っている家をセットバック寸るのならば、そのための メンテナンス費用は出すが、新築する場合には、道路から下げない と新築の許可を降ろさない、そのとき広くなった分の土地は地権者 から提供されるしくみになっている、ということであった。このし くみに対して地権者は納得の行かないやり方であるという少なから ぬ不満を持っていた。

\section{3. 調査方法}

(1)歩道利用者、(2)沿道地権者、(3)地域に住む人びと、に対して以 下のヒアリングおよびアンケート調査を行い、(4)地域へ調查結果を フィードバックすることにより、地域の人びとの積極的な意見を引 き出した（図 2)。

(1) 歩道利用者の調查対象者は、木下街道沿道にある法典小学校 6 年生児童（154 人）およびその保護者（136 人）と、沿道にある バス停利用者である。児童は小学校の教室内で、保護者は自宅で 回答した ${ }^{7)}$ 。バス停利用者は、バス停に記述用紙 25 枚を 1 週間 置き、23 人から有効回答が得られた ${ }^{7)}$ 。「下街道歩道の環境に ついて感想や意見を自由に書いて下さい」という質問に、文章で 回答していただいた。調査側の染意が入りにくい状態で、できる だけ普段意識にのぼっている問題点や要求、感じていることを知 るため、自由に意見を書いていただく形の調査を行った。

(2) 沿道地権者へは、あらかじめ許可を得た 70 代の男性地権者 2 人 に対して各地権者宅へ訪問し、木下街道を含めたこの地域に対す る思いについて、昔のこの地域と今との違いなども含めて聞かせ てください」というヒアリングを行った。それぞれ約 1 時間思い を聞かせていただいた。

(3) 地域の人々に対しては、住民主体の地域環境改善例として考えら れる場所、すなわち調查対象地内において地域の人々がつくった と言われている風景のある場所へ行き、その地を毎日手入れする ためにやって来る 60 代の女性にヒアリングを行った。

以上(1)(2)(3)アンケートとヒアリングの分析により、旧・新住民の 地域環境改善に対する意識の差異を明らかにした。その結果を、以 下(4)報告会と(5)勉強会の場にフィードバックし、(4)(5)(6)の場で積極 的な意見を聞かせていただいた。

(4) 2009 年 2 月に法典小主催による本調查報告会で PTA の方々 お話した。報告会終了後 PTAの方から多くのご意見をいただいた。

(5)さらに 2009 年 6 月に、地区自治会町会連合会主催の「法典地区 の大気污染と地域環境に関する勉強会」が開かれた（以下、勉強 会)。その勉強会において「幹線交通路化した生活道路沿道市街地 の地域環境に関する研究一船橋市立法典小学校区を事例に一」と いう題目で、これまでの調查分析結果を筆者が地域に報告する機 会が得られた。行政および歩道利用者と地権者それぞれの立場か らの意見をまとめ、地域の歴史とともに地域環境改善への手がか りについて報告を行った。そのとき出席した地域住民から現在の 地域の状況に対する様々な意見や要望が出された。さらに約 80 名の出席者の中から 30 名の方が任意に意見や提案、自分にでき ることを具体的に文章で記した。30名のうち男性は 17 人（平均 年齢 60 代、最高齢 80 代、最小齢 40 代)、女性は 13 人 (平均年 齢 30 代、最高齢 60 代、最小齢 10 代）であった注2)。
(6) また、駅前の小さな飲み屋には、親子 2 世代の担任だった法典 小の先生を囲んで、もと生徒達が年に数回、定期的に集まってい る。地元で仕事を持つ 40 代後半の主婦が多い。(5)勉強会への 出席者がいたことから、そのうち 4 人の主婦と 1 人の男性に木下 街道歩道の環境について語っていただいた。

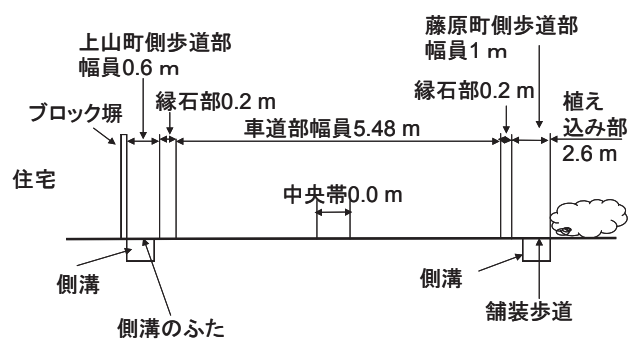

図 4 歩道（図 2 (1)）の断面図

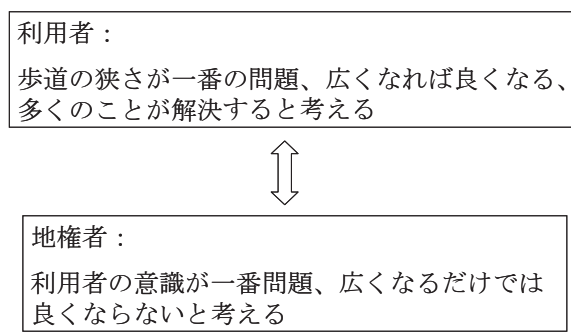

図 5 地権者と歩道利用者の見解の相違点

表 2 地域の人びとの変化

\section{報告前}

・産業用道路で大型車が通るのに、歩道は狭く、 雨水の排水がひどすぎる。早く安全な歩道 環境にしてもらいたいとず一っと思っている

・早く広げてほしい。新しい家が建つても歩道を 広げていない。法律の整備も緩和だけでなく 必要なところは厳しくしてほしい。

・少しの雨でも歩道や車道に水溜りがあるため、 長靴じゃなくては通れないような場所があったり、 車に水をかけられることもいつもありとっても ひどい。

・何年も前から歩道を広くしてほしいと 話題に出るがあまり進展もないようで、 なかばあきらめの気持ちになる

-とても不便でいやな道路です。もっと前から知って いればここに住むことはなかったと思います。 $\cdots \cdots$

\section{報告後}

・雨が降ると木下街道の水溜りがひどく歩道を歩く 児童がずぶぬれになっています。道路（歩道下） の排水口にたまったゴミや枯葉のそうじなどは、 声をかけあってできるのではないかと思います。

・もっとコミュニケーションをとりあえる場をもつ、 参加する、借りる側は感謝をもって使わせて いただく、知らない人に伝える

・沿道住民だけでなく地域住民全体で環境保全に 協力する必要があると思います。私達は年2回 木下街道等のごみ拾いや活動を行っています。 今後も続けたいと思います。

・通勤で法典駅までの徒歩が心地良いものになれば

うれしいです。実現するにはさまざまな問題が

あると思いますが行政が動いて地域が一体と

なれば必ず実現できると思います。

法典地区をすてきにしたいですね 


\section{4. 歩道利用者と沿道地権者の見解}

\section{1 歩道利用者の木下街道歩道に対する感じ方}

自由記述アンケートの中では、保護者および児童両者ともに、約 6 割が木下街道歩道を「狭い」と記した ${ }^{7)}$ 。バス停利用者は、全員 が狭いことを指摘した。さらに「トラックに吸い寄せられる」「死と 隣り合わせ」など、狭さと危険性の指摘や恐怖を感じているという 記述があった（図 3)。「子供の行き帰りで一番心配な道です」とい う記述は、30 代の主婦から出され、さらにヒアリング時に 70 代の 主婦からも同様の声が出されている。70 代の主婦は子供が小学校へ 通っていた頃いつも心配していたことを述べていた。また、もと生 徒達の 40 代主婦達からも出された言葉であったことから、異なる 世代で同様の感じ方を木下街道歩道に対して抱く住民がいることが

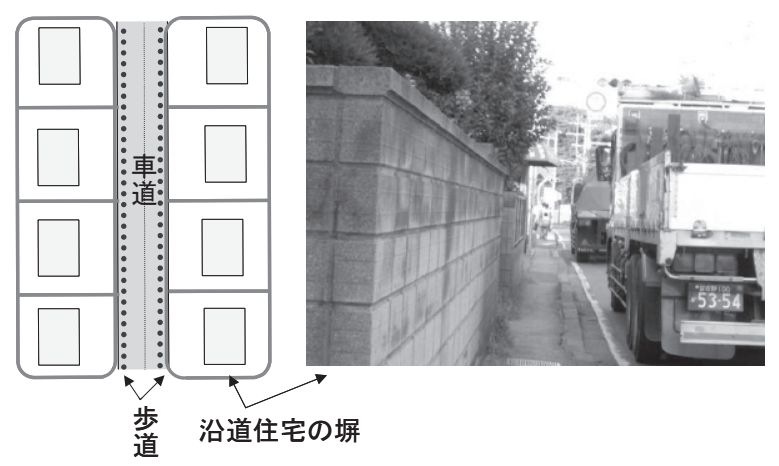

図 6 車道と塀との間の歩道

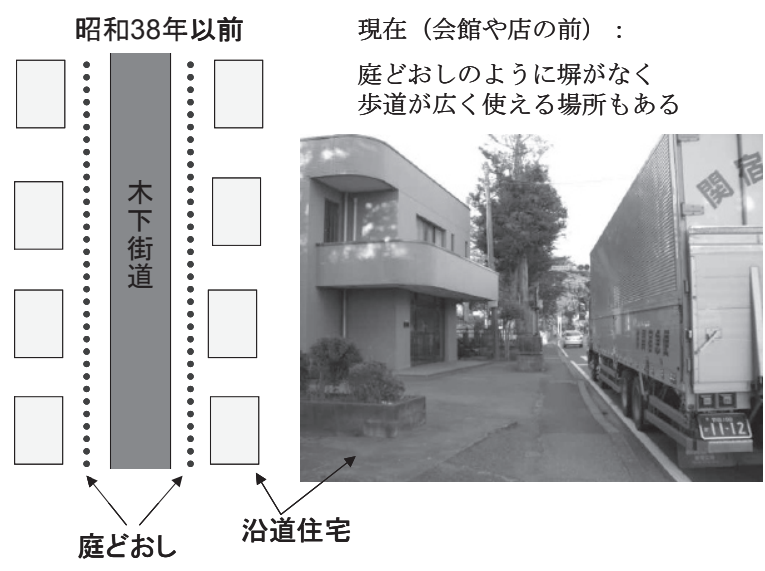

図 7 昔の庭どおしと現在の塀が無く空けてある場所

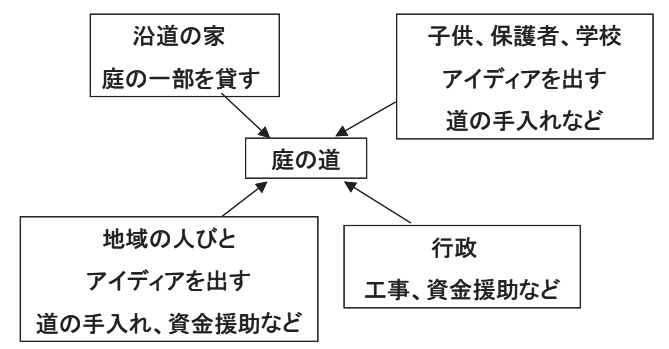

図 8 皆で少しずつ出し合ってつくる道
わかった。

さらに地権者にたいして、地主さんの方が改善に協力的ではなく、 永久に歩道は広がらないと聞いている」など地権者に対する不満の 声も見られた。

\section{2 地権者の地域への思い}

一方、沿道地権者も歩道利用者であるため、利用時の大変さにつ いては歩道利用者と共通の認識を持っていた。

さらに拡幅のために土地を提供することについては、「先祖代々受 け継いだ土地だし、少しぐらい公共のため、地域のために使うこと はなんともない。ただし、広くしただけではこの地域は良くならな い。」という考えを持っていた。すなわち、「歩道が広くなっても、 少しでも壁や塀などが出っ張っている印象をうけると、苦情が来る」 「歩道で雪かきなどの作業をやっていると、邪魔だと言われる、地 域の人のために便宜をはらっていてもそれが通じない」「挨拶がな い」勝手に植物を盗ったりゴミをすてたりする」など増え続ける歩 道利用者のマナーの悪さや、皆が自分本位であることのために生じ ている様々な沿道住民の苦労をあげていた。地域のために協力する 気持ちがある点および沿道利用者の意識の問題が根本にあると考え ている点については、 2 人の地権者はどちらも同意見であった。

\section{3 利用者と地権者の見解の相違点}

歩道利用者は歩道の狭さを一番の問題としており、広くなれば多 くのことが解決すると考えているのに対して、地権者は、歩道利用 者の意識を一番の問題と考えており、広くなるだけでは良くならな いと考えている点に両者の大きな違いが見られた（図 5)。この差が 生じた背景の一つには、歩道利用者と地権者とのコミュニケーショ ンの不足があるのではないかと考えられた。

すなわち地権者は「坦根を造らず開けておくと、一方で皆が勝手 に駐車に使い、その一方で車で強盗に来るのがいるかもしれないか らふさげと言われる。」「通行人が勝手に植物を持っていく、一言声 をかけてくれれば気持ちよく渡せるのに・・そういうことを防ぐた めに皆、丈夫な垣根やって鍵かけてということになる」「よそから来 たものに対しても、皆通りで挨拶をする地域がある。そういうとこ ろでは犯罪は起こらない。まず皆が挨拶をする。皆がそういう気持 ちになれば、まちを見守る風潮が出る、みなの意識を変えることが 重要だ」という地域に対する思いを持っていた。

\section{5. 歩道環境改善への手がかり 5.1 地域の人びとの変化}

表 2 に示すように地権者の思いを含めた報告を行う前の歩道利用 者へのアンケート調査では、ほぼ全員の意見が「なんとかしてほし い」「安心して通れる歩道にしてほしい」「理想を言えば、歩道も広 くなり小さい子供からお年寄りまでゆったりと歩ける環境・・」「・・ していただけたらこんな嬉しいことはございません」といった他者 への要望や願望とあきらめの声のみしか見られなかった。都市計画 区域決定と市町村合併による都市の拡大は、共同体の自治体系を解 体し、住民主体型自治から行政依存・行政請負型へと変遷していっ た ${ }^{13)}$ とあるように、本地域でも都市計画区域は 1970 年に告示、 用途地域は 1973 年に決定され、これまで地域が主体だった道路整 備などの事業が行われなくなり、行政依存型の住民意識が定着して いったと推測される。 
地域一の報告会および勉強会で、本調查の結果を地権者の思いも 含めて伝えさせていただいた結果、以下（5.3）のように、地域の人 びとから地権者への気遣いとともに、自分が地域でできることの提 案などの積極的な意見が出された。

\section{2 地域の知恵「庭どおし」}

地権者へのヒアリング時に、狭い歩道改善のための良い知恵が何 かありませんでしょうかと筆者が地権者に尋ねたところ、昔行われ ていた「庭どおし」について教えていただいた。現在歩行者は、一 般住宅の周囲が塀で囲まれているため、車道と塀との間のわずかな 寸き間を歩道として利用している状態である（図 6)。しかし舗装道 路になる前には、地権者の話しによると、「昔は木下沿道の家々には 坦根は無かった。・・庭どおし』と呼ばれていた。木下の道が非常 に悪かったから、みんなの便利のため、各家の庭を通り抜けること ができるようになっていた・・昭和 40 年頃までは通れた」という ことであった。

勉強会で現代版庭どおしについて提案の形で報告した際、「木下街 道の交通問題は生活道路が死と隣り合わせになっているのが現状で す。古きよき時代の『庭どおし』というすばらしい慣習を、現代版 として緑の歩道を提案されましたが、ぜひぜひ地域の若手後継者を 中心として、協議いただきたいと思います（60 代男性）」という意 見が出された。

現在も店や会館の場合には、塀で囲っていない場所があり、図 7 に示すように車道と建物との間に空間があるため歩道が広く使え、 庭どおしのようになっている。庭どおしを現代の形に合わせてもう 一度考えなおしてみることは、歩道拡幅とコミュニケーション促進 の場のための一つの手がかりとなるのではないかと考えられる。多 様な属性を持った居住者同士のコミュニケーションとそれと密接に 関わるかたちでの環境形成活動を分析した研究 ${ }^{9)}$ として、横道や裏 道、隣接した隣家の敷地をつなぐ通路などに着目したものがある。 分析では、こうした通路が、現代の多様な居住者属性のライフスタ イルに柔軟に対応していること、農地や農業施設を合理的に貸し借 りし、農業従事者だけではなく、高齢者や会社勤務者などの非農業 従事者が積極的に隣家と交流でき、様々な隣家関係パターンを形成 していることを明らかにしている。本対象地の沿道においても、児 童の登下校時だけでも庭を通り抜けられるように開けてもらうこと、 地域の人びとがその小さな道を皆で気持ちよく利用できるように、 沿道住民だけではなく、児童と保護者、地域の人びとがともに管理 することで、持続的な沿道地域のコミュニティが生じるきっかけに ならないだろうか。そのことにより、皆が挨拶をするなど意識の変 化が起こり、交流の輪が地域へ広がり、歩道問題だけではなく、地 権者が最も問題としている地域の人びとの意識改善へとつながる可 能性が期待できる（図 8)。

\section{3 新たな空間づくりのために必要なこと}

現代版庭どおしの実現のためには、(1)沿道住民との合意形成によ る借地が可能か、(2)借地が行えたとして、近所で話しをすることも なくなった現在、どのように管理活動を行い、それを伝えていけば よいのかということが問題となってくる。

\subsection{1 借地について}

行政側（県）は、相続の問題が発生するため県が土地を借用する ということはあり得ないとのことだった。地元自治会メンバーは、
「(沿道地権者から借地して利用するというのは）良い考えで、県に よる拡幅が無理になったら、取り入れることを考える必要も出てく るかもしれない」とのことだった ${ }^{8)}$ 。

道路拡幅のために法律による強制的な土地獲得という手段が多く 行われているが、つくば市中根金田台では、土地所有者から地代と 固定資産税を借地料と同等にすることにより、長期間つくば市が借 りる形で、沿道を景観緑地にする計画が進んでいる注3)。まだ使用 収益が開始されておらず、相続等の問題についても、これから管理 組合を立ち上げ地権者規約に基づいて管理をしていく準備段階とい うことであったが、地権者の方で 70 年の定期借地を考えていると のことであった。本論文対象地の問題とは異なり道路から $12 \mathrm{~m}$ が景 観緑地というゆとりある土地での区画整理事業の話しであるが、 UR と市が支援しイメージを定着させた上で賛同した地権者から合 意形成を行っている。法典地域では、将来像の共有と合意形成をつ くりあげていく場が非常に少ない。

勉強会では、「住民の協力によって環境がよくなるのであればこの ような勉強会にたくさんの人が参加し、意見を言い合えたらいいな と思います (40 代女性)」「何をすればよいかわからないので教えて くださる方や機会をつくっていただければ、それに参加し学んでい

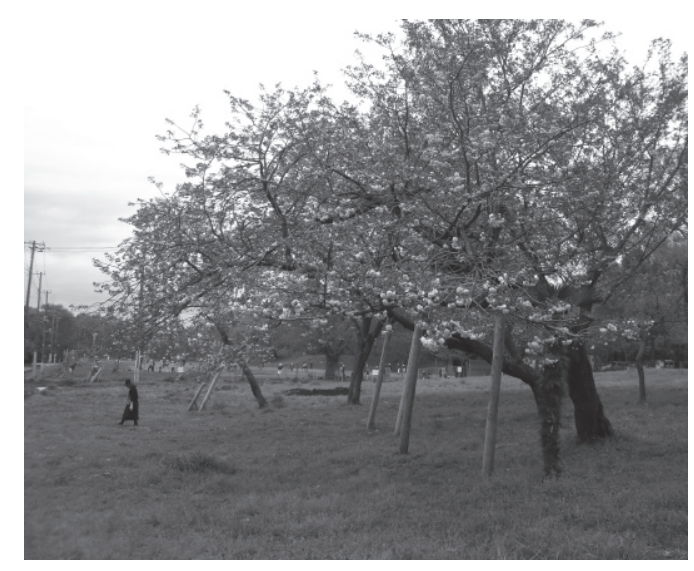

図 9 地域の人びとが 30 年以上かけてつくった風景 評判の桜、枝が折れないよう支えが入っている

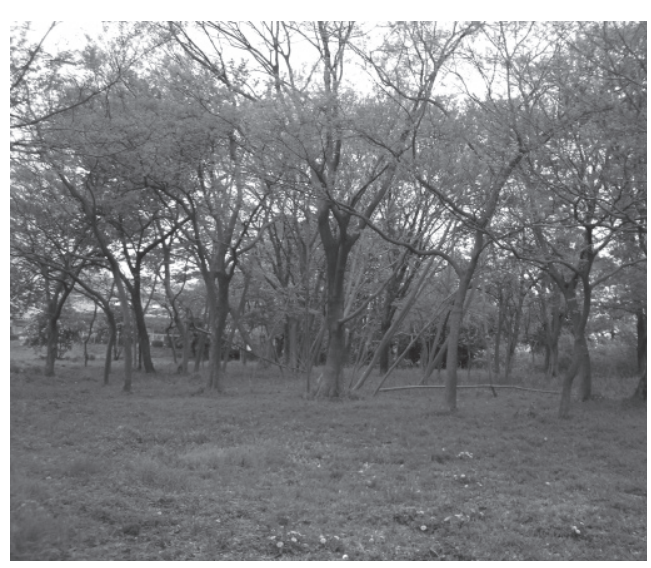

図 10 住民が選んで手入れしてきた木々 下草が刚られ見通しも良い 
けたらと思います。(40 代女性)」というように話し合いの場を求め る声があがった。

独自の防災機能向上のための手法を選択寸るには、地域住民の多 くが賛同できるアイデンティティの根幹についての共通認知、住民 の定住意識や地域への愛着が極めて重要なものとなってくるといわ れている ${ }^{6)}$ 。本地域の場合、庭どおしは歩きにくい道を使いやすく し、地域交流を促進するための独自の知恵であり特徵である、とい うことを認知する住民が勉強会などで増えたとき、地域共通のアイ デンティティとして地域改善のための原動力になる可能性が考えら れる。

\subsection{2 管理について}

管理活動については PTA をやっている保護者の話によると、「昔 は遠回りをしなくても、目的地へ行けるよう道（畑や住宅周囲の小 道など）を使わせてくれた地主さんがたくさんいた。利用者が草取 りをするなどそこを手入れすることもあった。世代がかわるにつれ、 その道は通れるのが当たり前みたいに思う人が出てきて、管理が悪 いと地主さんへ苦情がいくようになり、地主さんは次々と道を閉じ てしまった。今でも閉じられてしまう道がじんどん増えている」と のことだった。

勉強会で出された住民からの意見の中には「もしかしたら私有地 と知らずに毎日通ったりしているところがあるのかもしれません。 それを知る手がかりを作ってもらえたら (町会自治会などで)、子供 達や地域で協力して掃除などできるのではと思います。法典グラン ドを子供が野球で使っていたときには、親子で一緒に草刈りをしま した。その場所を使う人はお世話になるお礼として環境をよくする のは当然の義務だと思います。(40 代女性)」「私有地であることを 掲示して住民の人達に伝える必要があると思います。(60 代男性)」 という提案も見られた。

利用者同士および地権者との私有地の手入れなどの交流活動が伝 わらなくなっていることについて、沿道住民の話によると本地域の 人びとは、昔は神社の氏子などの集まりで、情報交換を行ったが、 今は日中若い人達が参加することができず、次世代へ情報が伝わら ないとのことだった。また近所で話しをすることも無いとのことだ った。コミュニティ形成に大きな役割を果たすキーパーソンの研究 において、地区のコミュニティが継続している大きな理由は、同じ 人がずっとキーパーソンであり続けるのではなく、数多いキーパー ソンが少しずつ交代して更新されることである ${ }^{1)}$ とある。本地域で も少しずつ交代して情報を更新していくことのできる場が必要であ る。情報交換の一つの場として公民館などで行われる様々な地域の 催しが考えられる。2010 年の法典文化祭や地域際では、地域の若者 による音楽演奏会や地域の大樹の紹介などが行われていた。法典地 区文化委員会が、地域の若者の活動を育てること、地域の緑の寸ば らしさを住民に伝えることを積極的に考えている。このような場で 情報交換が行われることにより、さらに地域の知恵が出される可能 性が考えられる。

また、ミニ開発建売住宅地における近隣コミュニケーションの研 究には、公民館や公的なコミュニケーションの場ではなく、私的で 任意選択的な飲み屋、集散自由な小さな住民コミュニケーションの 場が、現代のコミュニティでは重要になっているとある 10$) 。$ 本地域 では駅前の小さな飲み屋で、親子 2 世代の担任だった法典小の先生
を囲んで、もと生徒達が定期的に集まっている。PTA 役員や PTA 会長を経験した人、町会長を務めている人もいる。旧住民の親族が 入ることもある。主に 40 代後半の女性達である。もと生徒達は地 元で就職し地域のことを良く知っている。飲み屋には 5,6 人のグル ープで 4 組ぐらいの客が常時来ているということだが、もと生徒の 中には、飲み屋に来ているすべてのグループと交流のある人もいる。 キーパーソンの中には、グループリーダー的な人物もいるが、人と 人のつなぎ役という役割を果たしている人がほとんどである ${ }^{1) 、 と ~}$ あるようなキーパーソンがいると考えられる。常に同じキーパーソ ンであり続けるわけではなく、PTA 役員のように子どもの成長に合 わせて交代する人もいる、活動当時知り合った地域の人との交流は その後も続く場合が多い 1 )、とあるような活動当時の知り合いとの 交流は、もと生徒達も長く続いているようである。

もと生徒達は、木下街道の歩道環境について少しでも良くなれば という点では一致していた。もと生徒の男性は、具体的に交通量削 減のためのアイデアを聞かせてくださった。女性達は、自分たちの 考えをどこへどのように持っていけばよいのかわからないというこ とを述べていた。

住民グループの中でも自治会を中心とするグループは、組織力や 機動力があることが指摘されている ${ }^{15)}$ 。本地域の交通安全委員会を 中心とする自治会グループは、これまでの活動をみると確実な組織 力や機動力を持っている。様々なコミュニティで出された考えが、 自治会一集約され地域の提案となったときに、地域環境改善の可能 性が明確になると考えられる。

\section{4 地域の共有財産としての風景}

地域の中の改善例を参考にすることは、地域に合った解決策を見 出すことにつながる可能性が高い。本地域には、30 年以上かけてつ くってきたと地域の人が言う風景がある（図 1 、図 9、図 10)。集 合住宅（牡鹿台八イツ）と中学校との間にある空き地を地域住民が 管理してきた。長期にわたり土地の手入れを続けてきたこの場所の 取組みについてヒアリングを行った。

牡鹿台ハイツに住み毎日手入れをしに来る 60 代の女性の話によ ると、以前その場所は背丈以上の雑草が生い茂り、見通しが悪く治 安が悪かったので、牡鹿台ハイツの住民（主に退職した 60 代 70 代 の人びと）が、地主さんの許可を得て草を刈り手入れをしてきたと のことだった。最初はボランティア、すなわち活動のための収入を 一切受けず、また献金などによる団体としての活動資金もない状態 で、集まれる住民のみが作業を行っていた。しかし数年もすると活 動に限界が出てきたため、話し合いの結果、手入れをする費用は自 治会費から捻出することになった。管理活動を次世代へつなげるた めにボランティアにせず、基本的な活動費は自治会費などから捻出 し定期的に続けられる 60 代 70 代の世代の力を活用したことが、活 動を継続できた一つの理由と考えられる。現在は、この風景の場所 の管理活動は、退職した人達の良い活動の場になっているとのこと であった。皆でその場所にたくさんあった草木の中から、風景に合 う木、丈夫で手入れが少なくてすむ木を残して風景を創ってきたと のことである（図 10）。樹木の手入れ方法は、住民の誰かが他の場 所へ行って勉強し、樹木に縄をかけたり、薬を塗ったりする方法を 皆に伝えた。その女性は「特に桜の季節がきれいで他の場所ではあ まり見ない緑色の花の桜もあるんですよ。通行する人びとが皆きれ 
いだと言ってくれてうれしい・・ここの風景は 30 年かけて私たち が創ってきた風景なんです・・。」と感慨深そうに述べていた。樹木 の手入れをしてきた人びとだけではなく、近所の人びとの目を楽し ませる風景になっており、これらの人びとにとっては、生活感情と 一体化した風景となっているものと考えられる。

本来地域のみどりの風景は、地域が慣習的に人為を加え管理して きた共有財産としての産物であるが、今や社会条件の大幅な変化か ら、その風景の育成管理主体は不透明になりつつあるといわれてい る ${ }^{15)}$ こうした中で本場所のような住民の主体的な環境づくりをひ ろげていくことは、住民の多くが賛同できる独自の環境が地域に広 がり、その取組みとともに地権者が求めていた住民の意識が変化し 安心安全な地域への改善につながると考えられる。

そのためには行政の支援も必要である。すなわち、行政の助成を きっかけとして自治会組織をはじめ地域住民が、新たに身近な環境 づくりを実践する事例も報告されている ${ }^{15)}$ 。身近な生活環境におけ るまちづくり活動は、共同・共有で利用する生活空間の場に関わる 問題への取組みであることから、行政と住民の協働が重要な鍵とな っており、その受け具としての行政の支援体制づくりが必要とされ ている ${ }^{15)}$ 。木下街道沿道の場合、新たに生垣を作る時に利用できる 生垣設置のための市の補助金制度が考えられるが、現在はこうした 制度が市には無くなっている。塀を柔らかな生垣にすることによっ て庭どおしの小道を創るなど、地域に合う地域改善のための助成制 度を住民が要望し支援体制を作っていくことも必要と考えられる。

\section{6. まとめ}

本研究は、住民の意識を通して幹線道路沿道地域における環境改 善の可能性について考察を行った。すなわち、アンケートおよびヒ アリング調查の結果、旧・新住民の間には、地域環境改善に対寸る 意識に差異のあることが明らかになった。しかし差異を埋めるため のコミュニケーションの機会が少ないことも明らかになった。この ことは歩道拡幅に対する協力にも影響を与えていると考えられた。 そこで、この差異をどのように埋め地域の中でコミュニケーショ ンを促進させれば、住民主体の地域環境改善へと動いていけるのか について、小学校が主催した報告会と自治会が主催した勉強会、さ らにキーパーソンと考えられる若い旧・新住民が集まる飲み屋など で出された声を通して考察した。

本調查から得られた手がかりを以下にまとめた。

1）最初のアンケート調查では、新住民の声は環境改善が進まないこ とへの不満のみだった。報告会と勉強会の場で旧住民の地域への思 いを新住民に伝えることにより、新住民側から出された声に変化が 生じた。すなわち、立場の異なる旧住民側への心遣いを含んだ積極 的な提案一と変化する兆しが芽生えた。このことから歩道拡幅の協 力を得るには、法律により強制的に行うよりも、地域のつながりを つくることが改善への近道ではないかと考えられた。

2）地域環境の話題について話し合う場について、自治会や小学校主 催の勉強会、若い世代の旧住民関係者と新住民が集まる地域の飲み 屋、法典地区文化委員会が、地域の若者の活動を育て地域の緑の寸 ばらしさを住民に伝えることを積極的に考え開催する地域際などが 考えられた。

3）コミュニティをつなげる存在として、地域に根ざした生活環境を
築き、様々なコミュニティと関係を持つキーパーソン的存在の 40 代女性達が考えられた。

4）様々なコミュニティで出された地域への積極的な思いや知恵が、 具体的な提案として機動力のある自治会交通委員会に集約されたと き、地域改善の可能性が明確になるのではないかと考えられた。

5）かつての慣習だった「庭どおし」を現代版として行うためには、 庭どおしの空間が地域交流を促進し改善する独自の知恵であり、す ばらしい特徴であるという意識を、地域の人びとで共有する必要が あると考えられた。

6）庭どおしのための場所は、沿道住宅の敷地内であり、公的な土地 ではない。しかし本地域には、住民が地権者の土地を借り 30 年か け主体的に手入れを行い創りあげてきた風景がある。こうした事例 のように、住民の多くが賛同できる独自の環境を地域で創りあげ共 有財産を広げていくことが、地域環境改善につながると考えられた。 7）地域で創る空間の管理活動を次世代へつなげるために、活動はボ ランティアにせず基本的な活動費は自治会費などから捻出し、定期 的に続けられる 60 代 70 代の世代の力を活用することが必要である。 さらに地域改善のための助成制度として沿道の生垣改修の補助を住 民が行政に要望し支援体制をつくるなど、行政と協働で生活空間の 場に関わる問題に取り組むための受け典を整えていくことも必要で あると考えられた。

今回の調查で、話し合いの場を求める意見が住民から出されたこ とを機に、今後こうした話し合いが積み重㸚られれば、将来、歩道 環境整備や景観づくりの契機となる可能性があり、ハードおよびソ フト面で、地域全体の環境改善に大きな意義をもつことになると考 えられる。

庭どおしのための空間づくりには、現在住宅を囲んでいる塀の撤 去が必要になる。都市部の旧街道、たとえば成田街道などでも、同 様に狭く危険な場所が見られる。本地域の庭どおしの知恵はこうし た場所でも参考になると考えられる。ただし塀を撤去した場合、交 通量の多い車道部から排出される排気ガスが、沿道住宅内や庭にど のくらい入り込んでくるのかという問題が生じる。そのため、沿道 にどのようなものがあれば、または無ければ、大気污染物質濃度を 低減化できるのか、具体的に調查する必要がある。この調査に基づ き、塀を撤去した場合の沿道部の材料やデザインなどについて地域 全体の環境改善の視点から、地域の人びと皆で検討寸ることも大切 である。

\section{謝辞}

本調查を行うにあたり、沿道地権者、自治会、法典小学校、地域 の方々、UR、行政の方々には、お忙しい中、多大なご協力を賜り 多くのことを教えていただきました。特に勉強会での報告にあたり、 住民を主体とした地域での今後の努力の可能性を感じさせる「勉強 会」という語をタイトルに入れて主催してくださった法典地区自治 会町会連合会、交通安全対策委員会、環境委員会の方々のご尽力が なければ、たくさんの地域の人々への報告は実現できませんでした。 皆様にこの場を借りて厚く御礼申し上げます。 
注

注 1) 既報作成時におけるヒアリングでは、県と自治会は買収という語を用い ていた。本論文を書くにあたり、本地域で行われている拡幅に関して、セ ットバックするときの土地は、買収か無償の寄付かを市へ確認した結果、 買収ではないとの話しであった。そのため、既報で「買収」としていた箇 所は本論文ではすべて別の表現に修正した。

注 2) 本勉强会では、主催者の地区自治会町会連合会会長の挨拶、船橋市役所 環境部環境保全課課長の大気環境に関する話、筆者の報告、が行われた。 その際、筆者が受付に「本報告に対するご意見ご感想等をお聞かせくださ い」という用紙を置かせていただいた。30名の方々の意見はそのときに寄 せられたものである。30 名から出された意見は、1. 行政関係機関に対し て、2. 私有地の利用について、(1)提案が出されました、(2)私有地を利用さ せていただく際に心がけたいこと、3. 地域全体の環境改善について、(1)一 人一人が心がけたいこと、4. 大気環境について、5. 地域という範囲につ いて、6. 歩道について、7．勉強会について、8，その他のご意見ご感想等、 の 8 項目にまとめ、「地域の環境かわら版〜2009 年みんなの声〜」という 形にして主催した自治会へお渡しした。

注 3)つくば市の TX まちづくり推進課および UR 中根金田台開発事務所担当事 業課にお話を聞かせていただいた。

\section{参考文献}

1）田口槙子, 曽根陽子：コミュニティ形成に果たすグループ活動とキーパー ソンの役割-1960 年代のミニ開発住宅地における近隣交流に関する研究 その 3-, 日本建築学会計画系論文集, 第 75 巻, 第 648 号 pp. 343-351, 2010.2

2）三国政勝, 中村攻: 新旧住民の住意識解析を通してみた地域住環境の問題 点一混住地域における居住環境整備の課題その $1-$, 日本建築学会計画系論文 報告集, 第 361 号 pp87-94, 1986. 3

3）三国政勝, 中村攻 : 新旧住民の利用からみた集会所および公民館の性格一 混住地域における居住環境整備の課題その $2-$, 日本建築学会計画系論文 報告集, 第 367 号 pp. 63-70, 1986.9

4）鎌田元弘: 都市近郊地域における混住化集落の類型化とその特性に関する 考察一その 2 コミュニティ形成の視点からみた新旧住民の混在形式の基礎 的検討-, 日本建築学会計画系論文報告集, 第 393 号 pp. 61-70, 1988. 11

5）鎌田元弘, 坂本淳二, 細矢健太郎, 西村昌彦：混住化農村地域における新住
民行政区のコミュニティ形成-混住化による再編過程を経た行政区を事例 として-, 日本建築学会計画系論文集, 第 555 号 pp. 215-222, 2002.5

6）富山育子 : 歷史的町並夕保全地域を対象としたコミュニティの活用による 防災機能の向上に関する研究一京都市産寧坂伝統的建造物群保存地区を久 一ススタディとしてその 1-, 日本建築学会計画系論文集, 第 547 号 pp. 193-200, 2001.9

7）奥平純子, 北原理雄 : 歩行者からみた狭险歩道の環境一千葉県船橋市立法 典小学校区の木下街道沿道一, 日本建築学会技術報告集, 第 14 巻, 第 28 号 pp. 567-572, 2008. 10

8) 奥平純子, 北原理雄 : 歩道環境の整備に関する調查一千葉県船橋市立法典小 学校区の木下街道を事例に-, 日本建築学会計画系論文集, 第 73 巻, 第 634 号 pp. 2703-2708, 2008. 12

9）大槻雅洋,森傑 : 屯田兵村の空間構成と現代コミュニティとの関係-敷地間 通路を就寝とした隣家間の環境形成に着目して一, 日本建築学会計画系論文 集,第 74 巻,第 639 号 pp. 1067-1073, 2009.5

10）曾根陽子,武田有紀：1960 年代のミ二開発住宅地における近隣コミュニ ケーションに関する研究一その 1 飲み屋の利用実態から-, 日本建築学会計 画系論文集, 第 608 号 pp. 11-18, 2006.10

11）梅宮路子,佐野育美, 岡崎篤行: 住民意見と集団の変容に着目した歷史的 市街地における目標都市像の合意形成過程一新潟県村上市における都市計 画道路の見直しを事例として一, 日本都市計画学会都市計画論文集 No. $42-3$, pp. $337-342$, 2007. 10

12）法典歴史研究会 : 法典のおいたち, 1982

13） 2011 年 6 月号地域新聞

14）澤田洋子, 中山徽, 西村一朗 : 神戸市長田区（旧須磨町）西代耕地整理組 合に関する考証一その 2 田園小都市での権利関係者及びユミュニティの変 遷より見た地域共同体づくり, 日本建築学会計画系論文集、第 619 号 pp. 85-92, 2007. 9

15）安里直美,池田孝之: 身近な環境づくりにおける住民主体の活動と支援に 関する実態と課題一沖縄県浦添市まちづくりプラン賞を事例に一, 日本建築 学会計画系論文集,第 566 号 pp. 89-95, 2003.4

（2010年12月 7 日原稿受理，2011年 8 月26日採用決定） 